\title{
ANALYSIS OF KEY INDICATORS THAT AFFECT THE EXPECTED BENEFIT OF CUSTOMERS WHEN USING LOYALTY CARDS
}

\author{
Jelena KONČAR, Radenko MARIĆ*, Goran VUKMIROVIĆ \\ Faculty of Economics in Subotica, University of Novi Sad, Subotica, Serbia \\ Received 09 February 2018; accepted 16 April 2019
}

\begin{abstract}
The aim of this paper is to define the significance of different indicators that affect the expected benefit of customers when using loyalty cards in the purchasing process in the retail sector. As the most important indicators that affect expectations while using loyalty cards, the following was tested: price discounts, more efficient service and rewards, personalized communication, payment option, better information, status symbols and additional benefits. The research was conducted on a sample of 552 holders of loyalty cards of the largest retail chains in selected Central Europe (CE) and South East Europe (SEE) countries. The values of indicators for different categories of customers and different markets can be determined based on the obtained results and conducted tests. The determined values of the indicators are the basis for the formation of a regression model that will serve the chain managers to optimize the loyalty programs in relation to the identified customer expectations.
\end{abstract}

Keywords: loyalty cards, retailing, retail sector, customers, customers' loyalty, customers' benefits, loyalty programs, CE and SEE countries.

JEL Classification: L81, L84, M31.

\section{Introduction}

Studies (Cho, 2019; Filipe, Henriques Marques, \& Fátima Salgueiro, 2017; Alina Elena, 2016; Kellgren, Moradi, \& Romppanen, 2007) show that development and management of longterm relationships of loyalty with customers are founded on placing a customer at the centre of business through well-planned, personalized and customized messages, which are available to them through loyalty cards. According to Kellgren et al. (2007), building trust relationships with customers based on loyalty cards is actually a formalized connection of customers who meet the requirements set by the seller. Customers make an effort to become "members" of the club of loyalty card users and in return they receive benefits that are only available to club members (Rao \& Kotian, 2018; Lovreta, Končar, \& Petković, 2013). Pesonen, Komppula,

*Corresponding author. E-mail: radenko.maric@ef.uns.ac.rs 
and Murphy (2019), and Vesel and Zabkar (2009), confirmed in their studies that loyalty programs that are built on the basis of loyalty cards increase the frequency and quantity of purchase. Emphasis is especially placed on the need to build long-term relationship with final customers that is based on two-way communication, quality service and mutual trust (Lovreta et al., 2013).

The results of these studies are important for the service sector, primarily the retail sector, due to direct contact between the seller and the buyer. Research shows that many retailers apply just loyalty programs implemented through a system of customer loyalty cards (Demoulin \& Zidda, 2008). According to Lovreta et al. (2010), customer cards make customers the members of retailer's loyalty program, and in fact, serve as a means of personalized access to retail customers that allows them numerous expected benefits such as price discounts, personalized communication, rewards, more efficient service, earning points, etc. On the other hand, expected benefits of these programs for retailers are reflected in the fact that they can create a database of customers, accurately determine the frequency and amount of purchase, learn about the habits of customers, etc. (Putra, Armanu, \& Sudjatno, 2019; Marić \& Kraleva, 2017; Demoulin, \& Zidda, 2008). There are a number of indicators that influence customers' expectations of using loyalty cards, so retailers, where possible, should formulate an actual set of indicators that will enable rewarding of loyal customers, accelerate sales, increase customer satisfaction and attract new customers.

Bearing in mind the mentioned aspects and indisputable importance of loyalty cards in the retail sector, the subject of this paper is the research of the expected benefits for customers in using loyalty cards in the retail sector of selected CE and SEE countries.

The aim of the research is to define the significance of different indicators that affect the expected benefit of customers when using loyalty cards in the purchasing process in the retail sector. The values of indicators for different categories of customers and different markets will be determined based on the obtained results and conducted tests.

Practical significance of this research is to help companies in the retail sector and management of retail stores discover which indicators relating to the use of customer cards should be developed and offered to the market, in relation to identified customers' expectations.

The paper is structured in the following sections. The Introduction describes the research subject and objective. Literature Review as theoretical background is related to previous researches on the expected benefits for customers, the importance of loyalty cards within the loyalty program, and their interdependence in the retail sector of selected CE and SEE countries. Research hypothesis, sample, variables, research procedures and the data processing method are presented in the section - Methodology. The next section Results analyses the obtained data and discusses the results of the conducted testing of research hypotheses. Discussion of the results obtained, definition of regression models and presentation of equations of expected customers' benefits in using loyalty cards are provided in the section - Discussion. Concluding Remarks summarized the most important results of the research, focusing on shortcomings and suggestions for future research. 


\section{Literature review}

\subsection{Significance and expected benefits from loyalty cards}

Authors consider loyalty cards as a tool for creating a long-term, profitable relationship between seller and customer based on satisfaction (Plazibat, Šušak, \& Šarić, 2016; VilkaiteVaitone \& Papsiene, 2016). A number of authors (Plazibat et al., 2016; Vesel \& Zabkar, 2009) believe that loyalty cards are made with the initial objective to increase the number of repeat purchases in sectors with strong competition, but taking into account that brand value is not decreasing. Berman (2006) differentiates between four types of loyalty cards: Type 1 members get a discount, Type 2 - gratis members get 1 unit for free, when they buy a certain number of products, Type 3 - members collect points based on cumulative purchases, and Type 4 - members receive a customized offer and communication. Loyalty cards most often promote the last type, which essentially embodies first three types defined and has a high degree of customization to specific groups of customers. According to Kyguoliene et al., the use of loyalty cards results in the creation of long-term relationships with consumers, only if the use of loyalty cards meets their expectations and brings them benefits when shopping. As a result, customers show loyalty and form a habit of repeated purchase (Khalil, Ullah, \& Khalil, 2018; Kyguoliene, Zikiene, \& Grigaliunaite, 2017).

The opinions of other authors should also be mentioned (Dorotic, Bijmolt, \& Verhoef, 2012; Kellgren et al., 2007), who argue that loyalty cards do not play a decisive role in building long-term relationships with customers and that their loyalty should be built on quality service, quality product, after-sales guarantees and service.

The main objective of introducing loyalty cards into the process of building long-term relationships with customers is the customer satisfaction and retention, and improvement of customer's experience when purchasing, which will be directly reflected in increased profits and market share of the company (Lovreta et al., 2010).

Although loyalty programs require additional investment and engagement of companies, the use of loyalty cards is an irreplaceable element for building long-term loyalty among customers, especially in terms of multichannel marketing. The most important benefits that retailers can have from the use of loyalty cards are reflected in creating a base of loyal customers that remain loyal to the company and its brand, while in critical business situations, they more actively participate in communication with the company in terms of giving suggestions for improving sales activities and maintaining the overall image of the company and its supply on the market through sharing positive attitudes, advice and information with other users.

\subsection{Significance of loyalty cards in the retail sector of the selected CE and SEE countries}

Need to study indicators that influence the benefits customers expect from using loyalty cards in the retail sector of selected Central Europe (CE) and South East Europe (SEE) countries arises from the growing potential of these markets. After the global crisis (2008), the retail sector in all observed countries recovered, which was accompanied by an increase in personal 
consumption (López, \& Martín, 2019; Plazibat et al., 2016). At the same time, concentration processes continued in all retail segments, which lead to an increase in the participation of the loyalty program based on loyalty cards in the business results of the leading retail chains (Lovreta et al., 2010). This is confirmed by the data, which show the fast-growing economic activity of the retail sector of $\mathrm{CE}$ and SEE countries with a share of the gross value of retail trade in the total GDP of about 10-15\% (Table 1).

Table 1. Retail sector of selected CE and SEE countries (period 2016-2018)

\begin{tabular}{|l|c|c|c|c|c|c|c|c|}
\hline & Serbia & $\begin{array}{c}\text { Monte- } \\
\text { negro }\end{array}$ & Croatia & Hungary & Slovenia & $\begin{array}{c}\text { Roma- } \\
\text { nia }\end{array}$ & Bulgaria & $\begin{array}{c}\text { Bosnia } \\
\text { \& Herze- } \\
\text { govina }\end{array}$ \\
\hline $\begin{array}{l}\text { Share of the gross } \\
\text { value of retail } \\
\text { trade in the total } \\
\text { GDP }\end{array}$ & $10 \%$ & $12 \%$ & $13 \%$ & $15 \%$ & $14 \%$ & $10 \%$ & $10 \%$ & $10 \%$ \\
\hline $\begin{array}{l}\text { Average turnover } \\
\text { in retail sector }\end{array}$ & 3 bil. $€$ & 1 bil. $€$ & 4.2 bil. $€$ & 4.2 bil. $€$ & 2 bil. $€$ & 5.5 bil. $€$ & 3.5 bil. $€$ & 2 bil. $€$ \\
\hline $\begin{array}{l}\text { Number of } \\
\text { employees in } \\
\text { retail sector }\end{array}$ & 182,000 & 25,000 & 189,000 & 410,000 & 96,000 & 440,000 & 198,000 & 132,000 \\
\hline
\end{tabular}

The observed CE and SEE countries represent an interesting area for research due to large economic differences between countries (EU member states: Slovenia, Croatia, Hungary, Romania and Bulgaria; transition countries/Non-EU member states: Serbia, Bosnia \& Herzegovina and Montenegro) making this region suitable for a comparative analysis on how indicators affect the expected benefit of customers from the use of loyalty cards. In addition, previous research in the region of CE and SEE countries that covered this issue, were limited to the analysis of customer loyalty and satisfaction from the perspective of marketing relationship (Grubor, \& Đokić, 2015; Jeftić, 2015), quality of service (Drinić, Vranješ, \& Gašević, 2014), company's business results (Plazibat et al., 2016), service performance (Carraher, Parnell, \& Spillan, 2009) etc., while academic researchers paid very little attention to the indicators that affect customers' expectations in terms of the benefits from using loyalty cards in the retail sector. The popularity of loyalty cards in the retail sector is also indicated by the number of cards and turnover within the loyalty program in the global market. For instance, in the USA, turnover through the loyalty program was over $\$ 6$ billion in 2015. In total, there were about 2,250 independent loyalty programs exclusively based on loyalty cards. Almost 200 millions of Americans are participating in a program. In the UK 45 million customers are participating in a program, while as much as 20 million customers in Canada is included in at least one loyalty program (Carter, 2016).

The following table (Table 2) summarizes the results of the most significant studies conducted on the market of selected CE and SEE countries, that relate to the significance of loyalty cards in the retail sector. 
Table 2. Comparative overview of selected CE and SEE countries

\begin{tabular}{|c|c|c|}
\hline & $\begin{array}{l}\text { Number of } \\
\text { loyalty cards } \\
\text { (million) }\end{array}$ & Research on market characteristics and level of use of loyalty cards \\
\hline Serbia & 2 & $\begin{array}{l}89.2 \% \text { of customers are interested to participate in the retail loyalty } \\
\text { programs which are based on loyalty cards because they consider that } \\
\text { their participation in such programs brings certain benefits in the } \\
\text { purchase process (Dunković \& Petković, 2015); The study conducted } \\
\text { by Danojević (2016) on the market of the Republic of Serbia indicates } \\
\text { that the demographic and economic factors such as education, age } \\
\text { and monthly income significantly affect the benefit customers expect } \\
\text { from loyalty cards. }\end{array}$ \\
\hline $\begin{array}{l}\text { Monte- } \\
\text { negro }\end{array}$ & 0.3 & $\begin{array}{l}\text { Studies show that loyalty programs based on the use of loyalty cards } \\
\text { help in establishing long-term relationships with regular customers, } \\
\text { increase their number, shape their behaviour and direct them to } \\
\text { purchase a particular product (Bakic, Hrabrovski-Tomic, Muhi, \& } \\
\text { Kovacevic, 2010). }\end{array}$ \\
\hline Croatia & 1.8 & $\begin{array}{l}\text { The study was conducted by Plazibat et al. (2016), the rank shows that } \\
\text { there is a clear difference in expected satisfaction between customers } \\
\text { who are members of the loyalty card club (average rank of } 4.3 \text { ) and } \\
\text { customers who do not participate in loyalty programs (rank 3.4). }\end{array}$ \\
\hline Hungary & 4 & \multirow{2}{*}{$\begin{array}{l}\text { The research realized in 2009, in CE countries (Hungary, Slovenia, } \\
\text { etc) on a sample of } 1.324 \text { owners of small retail stores shows that the } \\
\text { most important indicator, which affects customers' expectations of } \\
\text { using loyalty cards, is personalized communication with potential } \\
\text { customers (Carraher et al., 2009). }\end{array}$} \\
\hline Slovenia & 1.1 & \\
\hline Romania & 9 & $\begin{array}{l}\text { The most important functions of loyalty cards from the standpoint } \\
\text { of the buyer are: discounts, vouchers and gift products (Acatrinei \& } \\
\text { Puiu, 2012). }\end{array}$ \\
\hline Bulgaria & 3.5 & $\begin{array}{l}\text { The respondents from Bulgaria ranked price benefits and price } \\
\text { discounts as the most important indicators that affect the expectations } \\
\text { of using loyalty cards (Antonova, 2013). }\end{array}$ \\
\hline B \& H & 1.5 & $\begin{array}{l}\text { Customers as members of the loyalty card users club identify } \\
\text { themselves with popular brands and stores (Anić, Rajh, \& Bevanda, } \\
\text { 2012). }\end{array}$ \\
\hline
\end{tabular}

However, despite the unquestionable contribution and benefits the customers get through loyalty cards, a small number of academic studies is devoted to this issue in the CE and SEE countries. No study has combined and concretized the impact of indicators, such as price discounts, more efficient service and rewards, personalized communication, payment option, better information, status symbols, additional benefits, etc. Unlike other studies, this research seeks to determine the individual and overall significance of different indicators for the expected benefit of customers when using loyalty cards while respecting the specific characteristics of the level of development of national markets and customers themselves. The expected result of the research is establishment of regression models with selected indicators. Therefore, besides its scientific importance, this research has a significant practical contribution, since it will indicate to the management of retail stores in the CE and SEE countries those indicators that have statistically the most significant impact on the expected benefit of 
using loyalty cards, i.e. which indicators in relation to the identified expectations should be more optimized, developed and engaged in loyalty programs aimed at building long-term relationships of loyalty with customers.

\subsection{Interdependence of indicators and expected benefits from the use of loyalty cards}

The primary task of loyalty cards in the retail sector is to link customers to the offer package and the retailer's sales facilities, where customers are rewarded through loyalty programs according to their total costs, by offering them additional services (Kyguoliene et al., 2017). The main task of these cards is to increase the propensity of customers to choose a retail chain where they will make their purchase. Issuing loyalty cards, retail stores are trying to identify, reward and retain such customers. Customers should recognize which benefits they can obtain by using customer cards and by participating in loyalty programs.

Leenheer, Van Heerde, Bijmolt, and Smidts (2007) believes that customers positively react to and accept loyalty cards if they receive certain financial and non-financial benefits from their use. In that context, several key indicators have been analysed in the literature that influence the level of benefits customers expect from using loyalty cards, such as: 1) price discounts (Leenheer et al., 2007) imply that cardholders receive a discount on the value spent during purchase; 2) more efficient service and rewards allow holders of loyalty cards faster service on special cash registers, rewards in the form of gifts for a certain number of points collected (purchase), etc.; 3) personalized communication (Mercadé-Melé, Molinillo, Fernández-Morales, \& Porcu, 2018; Marić, 2017) aims to strengthen the relationship between the seller and the customer based on personal address and correspondence; 4) payment option (Lovreta et al., 2010) refers to certain forms of non-cash payments available to card users; 5) better information (Reinartz, 2010) implies that loyalty card users receive timely information about discounts, special offers, new products and services, etc.; 6) status symbols (Huberman, Loch, \& ÖNçüler, 2004) are intangible benefits related to the psychological feeling of satisfaction and reputation in an environment created by the possession of certain loyalty card (e.g., Gold cards offered by some supermarkets) and 7) additional benefits (Kyguoliene et al., 2017) that may be hedonistic and social, but also specific additional benefits such as cards used for purchases abroad, etc.

Precise definition of the significance of each of these indicators to the customers' expectations when using loyalty cards allow checking of customer satisfaction and actual loyalty, the analysis of their contribution to more profitable business of the company, keeping records of mistakes and weaknesses of loyalty programs, etc. In addition to its importance for customers, loyalty programs have multiple benefits for retailers.

In addition to better business results, more significant market share and higher volume of turnover in retail facilities, the retailers benefit from loyalty cards in the creation of a personalized relationship with current and potential customers. Loyalty cards provide retailers with the ability to create specific databases that contain information about each customer, customers' purchasing habits, frequency and amount of purchase, preferences for a particular brand, mobility, frequently asked questions and complaints. 


\section{Metodology}

\subsection{Aim and hypothesis}

The aim of the research is to define the influence and contribution of indicators that include price discounts, more efficient service and rewards, personalized communication, payment option, better information, status symbols and additional benefits to the expected benefit of using loyalty cards in the retail sector of the selected CE and SEE countries. The initial assumption is that mentioned indicators have statistically significant effect on the level of expected customers' benefits in the retail sector of the selected CE and SEE countries. In addition, dependence of these indicators on sociodemographic variables will be tested, such as gender, education level, age of respondents, monthly income and place of residence (rural vs. urban; EU vs. non-EU countries).

Previous research on the significance of indicators for customers' expectations when using loyalty cards (Kyguoliene et al., 2017; Acatrinei \& Puiu, 2012; Plazibat et al., 2012; Lovreta et al., 2010; Demoulin \& Zidda, 2008; Leenheer et al., 2007) analysed only individual impact of these indicators on meeting customers' expectations by retailers and their loyalty programs, hence the importance of this paper is in its systematization and the conjoint analysis of the impact on the level of expected customers' benefits in order to optimize retail loyalty programs and build a long-term relationship with customers in relation to identified expectations. Consequently, in the conducted research, selected indicators were those for which a different level of significance and direction of correlation with the expected level of benefits from the loyalty card can be expected. Each of 7 selected indicators will be evaluated as a separate hypothesis: $\mathbf{H}_{1 \mathbf{a}}$ : The price discount has a positive impact on the fulfilment of customers' expected benefits from the use of loyalty cards; $\mathbf{H}_{\mathbf{1 b}}$ : The better service and rewards system has a positive impact on the fulfilment of customers' expected benefits from the use of loyalty cards; $\mathbf{H}_{1 \mathbf{c}}$ : The personalized communication has a positive impact on the fulfilment of customers' expected benefits from the use of loyalty cards; $\mathbf{H}_{1 \mathbf{d}}$ : The payment options has a positive impact on the fulfilment of customers' expected benefits from the use of loyalty cards; $\mathbf{H}_{1 \mathrm{e}}$ : The better information has a positive impact on the fulfilment of customers' expected benefits from the use of loyalty cards; $\mathbf{H}_{\mathbf{1}}$ : The status symbols have a positive impact on the fulfilment of customers' expected benefits from the use of loyalty cards and $\mathbf{H}_{\mathbf{l g}}$ : The additional benefits has a positive impact on the fulfilment of customers' expected benefits from the use of loyalty cards.

Furthermore, the characteristics of retail market development degree, purchasing power, the level of accessibility of loyalty cards loyalty programs, as well as the demographic characteristics of the population, can result in different expectations of customers in different markets. Considering the differences in observed characteristics, the research will focus on identifying the differences between customers who differ by sociodemographic variables, such as: gender, education level, age, monthly income and place of residence (rural vs. urban; EU vs. non-EU countries). In this context, the following group of hypotheses is proposed: $\mathbf{H}_{2 \mathbf{a}}$ : The expected benefits of customers from using loyalty cards differ by the gender; $\mathbf{H}_{\mathbf{2 b}}$ : The expected benefits of customers from using loyalty cards differ by the education level; $\mathbf{H}_{2 \mathbf{c}}$ : The expected benefits of customers from using loyalty cards differ by the age of respondents; 
$\mathbf{H}_{2 \mathbf{d}}$ : The expected benefits of customers from using loyalty cards differ by the monthly income; $\mathbf{H}_{2 \mathrm{e}}$ : The expected benefits of customers from using loyalty cards differ by the place of residence (rural vs. urban) and $\mathbf{H}_{\mathbf{2} \mathbf{f}}$ : The expected benefits of customers from using loyalty cards differ by the place of residence (EU vs. non-EU countries).

\subsection{Measurement variables and instruments}

The research included several variables that were used for confirmation or rejection of set hypotheses. Independent grouping variables are respondents' level of education, gender, age, monthly income and place of residents (urban/rural; EU/non-EU countries). Independent variables of interval type measurements are indicators: price discounts, more efficient service and rewards, personalized communication, payment option, better information, status symbols and additional benefits. Each of the indicators is operationalized through five-point Likert scale (1-5 ratings). The dependent variable is the expected benefit of customers from the use of loyalty cards in the retail sector of the CE and SEE countries.

The expected benefit of customers was assessed on the basis of a questionnaire consisting of 12 items ( 7 questions refer to indicators, while 5 questions refer to sociodemographic variables). Respondents were asked to evaluate the significance of each analysed indicator for the expected benefit from using loyalty cards, whereby rating 1 indicates that the given variable has no effect on the customers' expectations, while rating 5 indicates that respondents expect a high level of benefit from that variable. The questionnaire is defined in such way that each indicator is operationalized through five-point Likert scale: 1) To what extent did loyalty card of Company X meet your expectations? 2) Picture a company that is perfect in all aspects. How close is Company X loyalty card to such an ideal? 3) How often in the future will you use loyalty card of Company X? 4) In a similar group of cards, the Company $\mathrm{X}$ loyalty card is most frequently used, and 5) How often do you forget to show your loyalty card when shopping.

\subsection{Sample}

The study included 552 respondents. The research sample is non-random and appropriate, and falls into the category of large samples. Furthermore, the distribution of respondents by significant properties shows normal distribution. Therefore, it can be estimated that it represents the properties of the entire population in the analysed market segment. The sample was uniform with respect to gender, i.e. there was $52.3 \%$ of female and $47.7 \%$ of male respondents. The largest number of respondents, $41.8 \%$ of them, had a university degree, $35.3 \%$ of respondents had secondary education, while the smallest number of participants in the study completed higher education (22.9\%). Most respondents were between 40 and 60 years of age (40.5\%), while there was about the same number of respondents in other two groups. There was $30.7 \%$ of respondents older than 60 , and $28.8 \%$ of respondents between 20 and 40. There was $63 \%$ of respondents from large cities, while $37 \%$ are from rural (underdeveloped) areas. Respondents in the sample were grouped depending on whether their country belongs to the group of EU or non-EU countries. Even in terms of this variable, the sample of the respondents is uniform when it comes to its size and structure: EU countries $-\mathrm{n}=$ 
283 , non-EU countries $-\mathrm{n}=269$. Observed by countries, the representation of respondents in the sample is: Hungary $(\mathrm{HUN})=58$, Croatia $(\mathrm{CRO})=72$, Slovenia $(\mathrm{SLO})=53$, Romania $(\mathrm{ROM})=48$, Bulgaria $(\mathrm{BLG})=52$, Serbia $(\mathrm{SRB})=108$, Bosnia and Herzegovina $(\mathrm{B} \& \mathrm{H})=$ 107, Montenegro $(\mathrm{MNG})=54$.

\subsection{Procedure and statistical analysis of data}

Survey of respondents' answers was conducted during May, June and July 2017 in selected $\mathrm{CE}$ and SEE countries. The survey was conducted by anonymous questionnaire, which was electronically forwarded to customers in major retail chains of the CE and SEE countries (Tesco, Mercator, Idea, Univerxport, Delhaize Maxi, DIS, etc.).

Data collected in the research were analysed by SPSS 20. Respondents' answers were described by descriptive statistics. Average values are presented, as well as deviations for each dimension. The accuracy of the set hypotheses is examined by different statistical analyses: Pearson correlation, Multiple regression analysis and One-way analysis of variance.

\section{Results}

Descriptive statistics for indicators and dependent variable of the expected benefit of customers from the use of loyalty cards is provided in the following table (Table 3). As it can be seen, the respondents believe that their expected benefit is mostly affected by price discounts $(M=3.69)$, the level of information $(M=3.55)$, additional benefits $(M=3.27)$ and efficiency of service and rewards $(M=3.24)$, while somehow less expectation is associated with the personalized communication $(\mathrm{M}=2.94)$, status symbols $(\mathrm{M}=2.34)$ and payment by customer card $(M=2.38)$. In addition to the descriptive parameters, Table 3 shows the descriptive statistics for the indicators.

Table 3. Descriptive statistics for indicators and dependent variable

\begin{tabular}{|l|c|c|c|c|}
\hline \multicolumn{1}{|c|}{ Indicators } & Min. & Max. & Mean & St. deviation \\
\hline Price discounts & 1.23 & 4.67 & 3.6875 & 1.39753 \\
\hline $\begin{array}{l}\text { Efficiency of service and } \\
\text { rewards }\end{array}$ & 1.00 & 4.33 & 3.2428 & 0.86797 \\
\hline Personalized communication & 1.33 & 4.67 & 2.9403 & 0.98659 \\
\hline Better information & 1.23 & 5.00 & 3.5509 & 1.24081 \\
\hline Payment option & 1.00 & 5.00 & 2.3802 & 1.26482 \\
\hline Status symbols & 1.00 & 4.67 & 2.3428 & 0.97852 \\
\hline Additional benefits & 1.23 & 4.67 & 3.2714 & 1.12879 \\
\hline Loyalty & 1.87 & 3.67 & 3.0806 & 0.49621 \\
\hline
\end{tabular}

The obtained results are expected, given that many studies (Filipe et al., 2017; Marić \& Kraleva, 2017; Vesel \& Zabkar, 2009) regard price benefits and discounts, as well as timely available and accurate information about a product or service as the most important vari- 
able of making a purchase decision. Recent studies attach high significance in the customers' expectations from the process of buying to the efficient and fast service system (Anđelković \& Radosavljević, 2018; Leenheer et al., 2007), as well as additional benefits (Kyguoliene et al., 2017).

Multiple regression analysis was used for testing the first group of research hypotheses $\mathbf{H}_{1 \mathrm{a}}-\mathbf{H}_{1 \mathrm{~g}}$, which based on a set of independent variables, in this case the indicators Price discounts, More efficient service and rewards, Personalized communication, Better information, Payment option, Status symbols and Additional benefits, tries to predict the dependent, criterion variable, which in this study is defined as the expected benefit of customers from the use of loyalty cards. The Enter method was used, which includes all variables in the analysis, and thus all variables start with the same initial value. Table 4 presents contributions for each indicator.

Table 4. Contribution of individual predictors to criterion variable description

\begin{tabular}{|l|c|c|}
\hline \multirow{2}{*}{ Model } & Stand. coefficients & \multirow{2}{*}{ Sign. } \\
\cline { 2 - 3 } & Beta & 0.000 \\
\hline Price discounts & $0.381^{* *}$ & 0.000 \\
\hline Efficiency of service and rewards & $0.302^{* *}$ & 0.066 \\
\hline Personalized communication & 0.207 & 0.000 \\
\hline Better information & $0.293^{* *}$ & 0.024 \\
\hline Payment option & $-0.326^{* *}$ & 0.010 \\
\hline Status symbols & $-0.227^{*}$ & 0.017 \\
\hline Additional benefits & $0.262^{*}$ & \\
\hline
\end{tabular}

Note: ${ }^{\star}$ Significant at the level $5 \%,{ }^{* *}$ significant at the level $1 \%$.

Based on the results of the conducted regression analyses, it can be concluded that a set of these indicators statistically significantly predicts criterion variable $(\mathrm{F}=15.964, \mathrm{p}<$ 0.01). The coefficient of determination is 0.66 while $43.5 \%$ of the expected benefit variance is described. If contributions of individual indicators are observed, it can be seen that the indicator Price discounts mostly contributed in a positive direction $(B=0.381)$ to the description of the criterion variance, which means that this indicator most significantly affects the benefit customers expect from using loyalty cards. Customers, as owners of loyalty cards, want to be rewarded for their loyalty, and as the biggest benefit they indicate the discounts granted by retailers to specific products or services to the members of the loyalty card club. Indicators that stand out are Better information $(B=0.293)$, Additional benefits $(B=0.262)$ and Efficiency of service and rewards $(B=0.302)$, which have a statistically significant impact on expected customers' benefit. On the other hand, Payment option $(B=-0.326)$ and Status symbols $(B=-0.227)$ have the influence in a negative direction. The only variable which according to customers does not provide benefit when using loyalty cards is the indicator Personalized communication.

Based on the obtained data, it could be concluded that the hypothesis $\mathbf{H}_{\mathbf{1 a}}, \mathbf{H}_{\mathbf{1 b}}, \mathbf{H}_{\mathbf{1 e}}$ and $\mathbf{H}_{1 \mathbf{g}}$ are confirmed. This means that correlations are confirmed for variables Price discounts, 
Efficiency of service and rewards, Better information and Additional benefits. In other words, loyalty cards that provide their customers with price discounts, more efficient service and rewards, better information and additional benefits are correlated to the level of benefits customers expect from their use in the retail sector of the selected CE and SEE countries. The hypothesis was not confirmed for variable Personalized communication $\mathbf{H}_{\mathbf{l c}}$, which means that emphasizing this indicator as a benefit that customers receive from the use of loyalty cards has no statistically significant impact on their expectations.

Hypotheses $\mathbf{H}_{\mathbf{1 d}}$ and $\mathbf{H}_{\mathbf{1 f}}$ are confirmed but in a negative direction. This means that emphasizing payment options and status symbols when using loyalty cards reduces the expected benefit of customers. The level of market development, types of implemented loyalty programs and payment methods can have a different impact on customers' expectations. For example, if loyalty programs are highly developed in a particular market, it is assumed that a relatively large number of customers will consider the use of loyalty cards as a common habit, and not as a status symbol. In contrast to the observed non-EU markets characterized by a lower level of use of loyalty cards and a lower volume of electronic payments, in the selected EU markets, the negative correlation indicates that customers do not perceive the use of loyalty cards as a status symbol nor they correlate it to a particular form or method of payment. In other words, if the use of loyalty card is conditioned by retailers with a particular form of payment, this implies a negative impact on the customer's expectations.

To test the second group of research hypotheses $\mathbf{H}_{2 \mathrm{a}}-\mathbf{H}_{2 \mathrm{f}}$, Multivariate analysis of variance was applied to examine whether the expected benefits of customers in terms of price, efficiency, personal communication, better information, payment option, status symbol and additional benefits differ from the sociodemographic variables - gender, age, education, income and place of residence. It was found that individual contribution was only realized through sociodemographic variable Place of residence $\mathbf{H}_{2 \mathbf{f}}$ (EU vs. non-EU countries). This means that customers differ in terms of the benefits they expect from using loyalty cards depending on whether the respondent's country of residence is EU member state or is in the process of joining the EU. The biggest differences between EU and non-EU customers are reflected in their expectations of: Price discounts $(\mathrm{F}=4.523, \mathrm{p}<0.01)$, Efficiency of service and rewards $(\mathrm{F}=5.281, \mathrm{p}<0.01)$, Payment option $(\mathrm{F}=2.481, \mathrm{p}<0.05)$ and Additional benefits $(\mathrm{F}=3.486, \mathrm{p}<0.01)$. Significant differences in the expected benefits of customers are partly manifested in another two sociodemographic variables: Monthly income $\mathbf{H}_{\mathbf{2} \mathbf{d}}$ and Place of residence $\mathbf{H}_{2 \mathrm{e}}$ (rural vs. urban). Monthly income generates a statistically significant difference for the variables Price $(\mathrm{F}=1.623, \mathrm{p}<0.01)$ and Payment option $(\mathrm{F}=2.294, \mathrm{p}<0.01)$, while Place of residence (rural vs. urban) has a statistically significant difference for the variables Price $(\mathrm{F}=6.912, \mathrm{p}<0.01)$ and Efficiency of service and rewards $(\mathrm{F}=5.847, \mathrm{p}<0.01)$, and the contribution of the dependent variable Additional benefits $(F=2.866, p=0.59)$ is on the margin of significance. Since customers' expectations do not differ in terms of the remaining sociodemographic variables $\mathbf{H}_{2 \mathbf{a}}-\mathbf{H}_{2 \mathrm{c}}$ (gender, education and age), the conclusion is that there is no statistical significance in the joint contribution of these five variables (Table 5).

Based on the Multivariate analysis of variance, it can be concluded that the second group of research hypotheses $\mathbf{H}_{2 \mathrm{a}}-\mathbf{H}_{2 \mathrm{c}}$ reading that there is a statistically significant difference between the expected benefits of customers in using loyalty cards and sociodemographic 
Table 5. Predictor contributions to the explanation of dependent variables

\begin{tabular}{|c|c|c|c|}
\hline & Dependent variable & $\mathrm{F}$ & Sign. \\
\hline \multirow{7}{*}{ Gender } & Price discounts & 0.319 & 0.728 \\
\hline & Efficiency of service and rewards & 0.115 & 0.891 \\
\hline & Personalized communication & 0.345 & 0.709 \\
\hline & Better information & 0.951 & 0.389 \\
\hline & Payment option & 0.371 & 0.691 \\
\hline & Status symbols & 0.891 & 0.413 \\
\hline & Additional benefits & 0.126 & 0.882 \\
\hline \multirow{7}{*}{ Education } & Price discounts & 0.610 & 0.545 \\
\hline & Efficiency of service and rewards & 0.137 & 0.872 \\
\hline & Personalized communication & 1.905 & 0.153 \\
\hline & Better information & 0.562 & 0.572 \\
\hline & Payment option & 0.349 & 0.706 \\
\hline & Status symbols & 0.809 & 0.447 \\
\hline & Additional benefits & 0.098 & 0.907 \\
\hline \multirow{7}{*}{ Age } & Price discounts & 1.942 & 0.148 \\
\hline & Efficiency of service and rewards & 0.516 & 0.598 \\
\hline & Personalized communication & 0.912 & 0.011 \\
\hline & Better information & 0.807 & 0.449 \\
\hline & Payment option & 0.642 & 0.528 \\
\hline & Status symbols & 0.857 & 0.427 \\
\hline & Additional benefits & 0.886 & 0.069 \\
\hline \multirow{7}{*}{ Monthly income } & Price discounts & $1.632^{* *}$ & 0.000 \\
\hline & Efficiency of service and rewards & 0.880 & 0.478 \\
\hline & Personalized communication & 0.524 & 0.719 \\
\hline & Better information & 1.059 & 0.379 \\
\hline & Payment option & $2.294^{* *}$ & 0.001 \\
\hline & Status symbols & 1.421 & 0.231 \\
\hline & Additional benefits & 0.340 & 0.850 \\
\hline \multirow{7}{*}{$\begin{array}{l}\text { Place of residents } \\
\text { (rural/urban) }\end{array}$} & Price discounts & $6.912^{* *}$ & 0.001 \\
\hline & Efficiency of service and rewards & $5.847^{* *}$ & 0.000 \\
\hline & Personalized communication & 2.215 & 0.071 \\
\hline & Better information & 0.589 & 0.672 \\
\hline & Payment option & 0.747 & 0.562 \\
\hline & Status symbols & 0.841 & 0.502 \\
\hline & Additional benefits & 2.886 & 0.059 \\
\hline \multirow{7}{*}{$\begin{array}{l}\text { Place of residents } \\
\text { (EU/non-EU) }\end{array}$} & Price discounts & $4.523^{* *}$ & 0.000 \\
\hline & Efficiency of service and rewards & $5.281^{* *}$ & 0.001 \\
\hline & Personalized communication & 0.578 & 0.057 \\
\hline & Better information & 1.785 & 0.050 \\
\hline & Payment option & $2.481^{*}$ & 0.011 \\
\hline & Status symbols & 1.451 & 0.062 \\
\hline & Additional benefits & $3.486^{* *}$ & 0.005 \\
\hline
\end{tabular}

Note: ${ }^{\star}$ Significant at the level $5 \%,{ }^{\star *}$ significant at the level $1 \%$. 
variables such as gender $\mathbf{H}_{2 \mathbf{a}}$, education level $\mathbf{H}_{2 b}$ and age of respondents $\mathbf{H}_{2 c}$ is not confirmed. Hypotheses $\mathbf{H}_{2 \mathbf{d}}$ and $\mathbf{H}_{2 \mathrm{e}}$ reading that the expected benefit of customers from the use of loyalty cards differs depending on the monthly income and place of residence are partly confirmed because the differences are noticed only in terms of expectations from Price discount (for $\mathbf{H}_{2 \mathbf{d}}$ and $\mathbf{H}_{2 \mathrm{e}}$ ), Efficiency of service and rewards (for $\mathbf{H}_{2 \mathbf{e}}$ ) and Payment option (for $\mathbf{H}_{2 \mathbf{d}}$ ). Within the analysed groups of respondents grouped by sociodemographic variables it isn't possible to predict the expected benefit of customers in using loyalty cards. In other words, the results show that respondents of different gender, levels of education, age, monthly income and place of residence do not differ in the level of benefits they expect from using loyalty cards in terms of Price discounts, More efficient service and rewards, Personalized communication, Payment option, Better information, Status symbols and Additional benefits.

Although most studies emphasize that higher expectations of a product or service are expressed in female customers, highly educated customers, customers with lower monthly income, customers from rural areas (Melnyk, Van Osselaer, \& Bijmolt, 2009; Bell, \& Eisingerich, 2007), etc., the justification of the obtained results is reflected in the fact that each customer expects the highest level of benefits from the use of loyalty cards regardless of sociodemographic differences.

In the analysed group of sociodemographic variables, the tests pointed to statistically significant differences only within the variable Place of residence $\mathbf{H}_{2 \mathrm{ff}}$ (EU vs. non-EU countries). Therefore, the focus will be on a detailed analysis of the deviations between these groups of respondents. A multiple regression analysis was used to determine the differences between groups of countries. The test results of the multiple regression analysis are presented in the following table (Table 6).

Table 6. Contribution of individual indicators to description of criterion variable in groups of EU/ non-EU countries

\begin{tabular}{|c|c|c|c|c|}
\hline \multirow{3}{*}{ Model } & \multicolumn{2}{|c|}{ EU member states } & \multicolumn{2}{|c|}{ Non-EU member states } \\
\hline & $\begin{array}{l}\text { Standard. } \\
\text { coefficient }\end{array}$ & Sig. & $\begin{array}{l}\text { Standard. } \\
\text { coefficient }\end{array}$ & Sig. \\
\hline & Beta & & Beta & \\
\hline Price discounts & $0.312^{\star *}$ & 0.001 & $0.411^{\star \star}$ & 0.000 \\
\hline Efficiency of service and rewards & $0.402^{* *}$ & 0.000 & $0.384^{\star *}$ & 0.028 \\
\hline Personalized communication & 0.358 & 0.074 & $-0.085^{\star}$ & 0.018 \\
\hline Better information & $0.151^{\star}$ & 0.040 & 0.083 & 0.612 \\
\hline Payment option & $-0.469^{* *}$ & 0.000 & $0.397^{\star}$ & 0.015 \\
\hline Status symbols & $-0.114^{*}$ & 0.048 & 0.515 & 0.078 \\
\hline Additional benefits & $0.324^{\star *}$ & 0.007 & $0.343^{\star *}$ & 0.001 \\
\hline
\end{tabular}

Note: ${ }^{*}$ Significant at the level $5 \%,{ }^{* *}$ significant at the level $1 \%$.

The obtained regression equations are statistically significant for each of the analysed groups (EU countries $-\mathrm{F}=4.748$; $\mathrm{p}<0.01$; non-EU countries $-\mathrm{F}=8.044, \mathrm{p}<0.001$ ) and it 
can be concluded that the differences between respondents from EU and non-EU countries statistically significantly affect the differences in the benefit customers expect from using loyalty cards. Given the data presented in Table 5, it can be concluded that the expected benefit of respondents from EU countries (CRO, SLO, HUN, ROM and BLG) may be predicted based on Efficiency of service and reward $(B=0.402)$, Price discounts $(B=0.312)$, Additional benefits $(B=0.324)$ and Better information $(B=0.151)$ in a positive direction, then Status symbols $(B=-0.114)$ and Payment option $(B=-0.469)$ in a negative direction, while personalized communication does not have a statistically significant impact $(B=0.358$; $\mathrm{p}=0.074)$. On the sample of respondents from non-EU countries (SRB, B\&H and MNG), the greatest contribution is achieved by Price discounts $(B=0.411)$ and Payment option $(B=$ 0.397 ) in a positive direction. This result is expected given that low purchasing power and the average value of a market basket that exceeds average net earnings on non-EU markets lead customers to make purchasing decisions based on the price, and they enter loyalty programs and become loyalty card users exclusively because of price benefits, different payment options and discounts in future purchases. In this group, a positive direction of expected benefit is affected by Efficiency of service and reward $(B=0.384)$ and Additional benefits $(B=0.343)$ while customers' expectations in a negative direction can be predicted on the basis of Personalized communication $(\mathrm{B}=-0.085)$. Indicators that do not have a statistically significant impact in the sample of non-EU countries are Status symbols $(B=0.515 ; \mathrm{p}=0.078)$ and Better information $(\mathrm{B}=0.083 ; \mathrm{p}=0.612)$.

The significance of indicators on the observed sample of EU/non-EU countries in the region of selected CE and SEE countries can also be graphically presented (Figure 1) in order to provide a clearer insight into the level of differences by individual indicator values in the regression model.

The conducted regression analysis confirms that there are statistically significant differences between customers from EU/non-EU countries in the expected benefit from using loyalty cards when it comes to price discounts, more efficient service and rewards, personalized communication, payment option, better information, status symbols and additional benefits. In other words, within the analysed groups of respondents (EU/non-EU countries), it is possible to predict expected customers' benefit with analysed indicators.

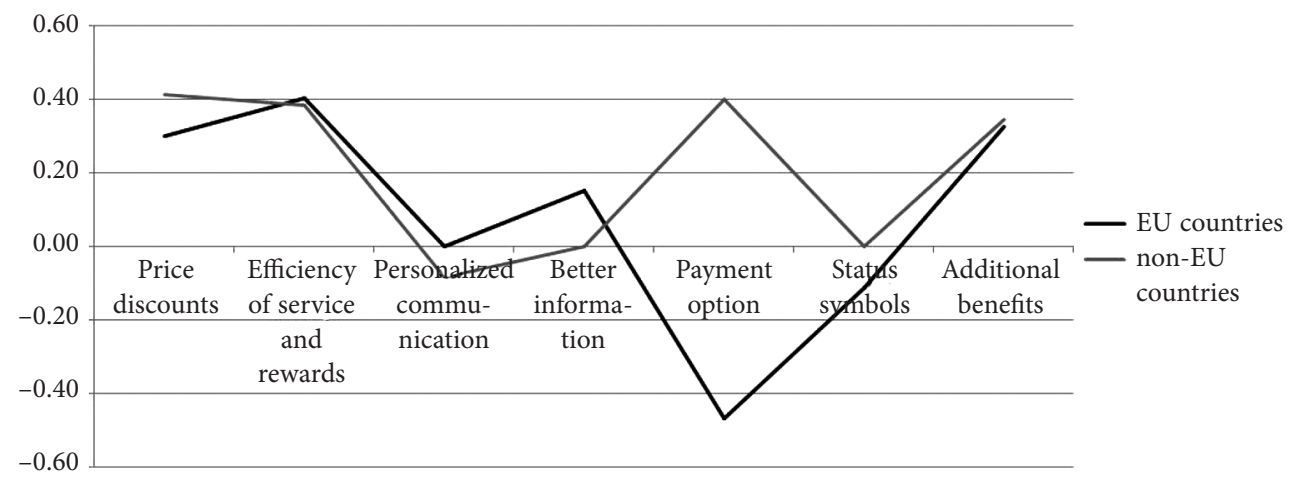

Figure 1. Differences in the expected benefit of consumers in terms of analysed indicators in groups of EU/non-EU countries 


\section{Discussion}

Conducted analyses and tests have shown that the expected benefit of customers from the use of loyalty cards in the retail sector of the selected countries is correlated to with price discounts, efficiency of service and reward, better information and additional benefits in a positive direction, while it is correlated with payment option and status symbols in the negative direction. Multiple regression equation on the total sample of CE and SEE respondents indicated that expected benefit can be predicted on the basis of selected indicators. The regression model (equation) that includes only the statistically significant contributions may be represented as follows.

$$
y=2.559+0.381 x_{1}+0.302 x_{2}+0.293 x_{4}-0.326 x_{5}-0.227 x_{6}+0.262 x_{7} .
$$

In the above equation, $y$ represents the dependent variable (expected benefit of customers), while the variables $x$ are independent variables, such as: $x_{1}$ - Price discounts; $x_{2}-$ Efficiency of service and rewards; $x_{4}$ - Better information; $x_{5}$ - Payment option; $x_{6}-$ Status symbols and $x_{7}$ - Additional benefits.

The equation shows that expected benefit of customers based on loyalty cards can be predicted on the basis of most of the indicators included in the survey. Acting upon the presented equation of loyalty indicates to the management of retailers that the growth of customers' benefit with price discounts, efficiency of service and rewards, better information and additional benefits is accompanied with the increased trust in loyalty programs based on the use of loyalty cards. Therefore, to improve the use of loyalty cards as an integral part of loyalty program in the selected CE and SEE countries, management of retailers should optimize, develop and promote these indicators as the most important benefits that are offered to customers through the use of loyalty cards with the ultimate aim of achieving greater benefit and thus higher loyalty.

This means that retailers must clearly and precisely present to potential loyalty card users all price discounts by types of products and services, they must be fully respected and employees in retail stores must act accordingly. These research results coincide with the results of Antonova's research from 2013, which defines price discounts as a key instrument of loyalty program (Antonova, 2013).

In the observed region, the respondents prefer the improvement of the service system and corresponding rewards with the appropriate scope and frequency of purchase. In that context, the management of retail facilities should provide the holders of loyalty cards with faster service on special cash registers, gifts for a certain number of points collected, etc. The focus should also be on better customer information, in terms of providing timely information on discounts, special offers, price reductions, new products, etc., as well as on providing other types of benefits (e.g. ability to use cards abroad).

Multiple regression equation for two subgroups of respondents from EU and non-EU countries showed that expected benefit of customers can be predicted by different indicators in each of the sub-groups. The next two equations represent the regression models of the benefit that customers expect when using loyalty cards in the retail sector of the selected CE and SEE countries, on a sample of EU (2)/non-EU countries (3). 


$$
\begin{gathered}
y=2.597+0.312 x_{1}+0.402 x_{2}+0.151 x_{4}-0.469 x_{5}-0.114 x_{6}+0.324 x_{7} ; \\
y=2.608+0.411 x_{1}+0.384 x_{2}-0.085 x_{3}+0.397 x_{5}+0.343 x_{7} .
\end{gathered}
$$

In these equations, $y$ represents expected benefit of customers, while $x_{1}$ - Price discounts; $x_{2}-$ Efficiency of service and rewards; $x_{3}$ - Personalized communication; $x_{4}-$ Better information; $x_{5}$ - Payment option; $x_{6}-$ Status symbols and $x_{7}-$ Additional benefits. Although most indicators act in the same direction, the number of indicators and their intensity varied according to testing region. Therefore, in the subgroup of respondents from EU countries, the efficiency of service and rewards have the greatest statistical significance, unlike respondents from non-EU countries who prefer price discounts. This deviation coincides with the results of previous research confirming that the price, as a result of low living standards, is the most important factor for making a decision on purchasing in transition countries (Tekić, 2018; Danojević, 2016; Končar, \& Marić, 2015). Furthermore, there is the indicator of Payment option that has a negative impact on customers' expectations in the sample of EU countries, while respondents from non-EU countries experience it as an essential component of the decision about using loyalty cards. The significance of the indicator - Better information in the sample of EU countries has a positive direction, unlike the respondents from transition countries who consider that the given indicator does not have a statistically significant contribution. It is interesting to note that when purchasing luxurious or highvalue products and brands, customers can have expectations regarding their status symbol. However, the expectations and possible loyalty to a particular brand may not be related to the use of loyalty cards. According to the stated expectations of respondents (especially from EU countries), the use of loyalty cards does not represent a status symbol, due to their wide use and accessibility, i.e. the use of loyalty cards is not an indicator of status and membership of a particular customer group.

The results are partially consistent with the results of related research (Danojević, 2016; Plazibat et al., 2016; Drinčić, Vranješ, \& Gašević, 2014) that customers' expectations statistically significantly differ in regard of the benefit they receive from certain indicators of the loyalty program in retail sector. Conducted analysis and testing, as well as presented regression models, show to the management of retailers how to improve their own loyalty programs, so that indicators that to the greatest extent, in accordance with the above regression models, affect the use of loyalty cards, are offered and promoted to a certain group of customers (EU/non-EU countries). In this way, retailers will shape customer loyalty and desire to re-purchase.

\section{Conclusions}

The need for the research of the benefits that customers expect when using loyalty cards in the retail sector in the selected CE and SEE countries, stems from the fact that it is a constantly growing sector of the economy where a very small number of academic research is dedicated to the issue. Data show that more than half of customers on the analysed market has a loyalty card, hence the need to conduct a research on this topic, in order to show to the management of retail stores how to focus and offer to specific customers the most 
appropriate loyalty programs with appropriate benefits and rewards. The research and conducted tests showed that statistically most significant impact on the use of loyalty cards is exercised by Price discounts (non-EU countries: SRB, B\&H and MNG) and Efficiency of service and rewards (EU countries: CRO, SLO, HUN, ROM and BLG). This is followed by indicators Better information and Additional benefits, having in mind that their intensity of impact varies and that other indicators also occur, depending on the group of respondents being tested. This reflects the practical contribution of this research that should indicate to the management of retailers which indicators should be promoted to a group of customers and developed in order to influence greater use of loyalty cards in purchasing processes. The research has shown that customers of different sociodemographic variables (excluding their place of residence: EU vs. non-EU countries) do not differ in the level of benefits they expect from the use of loyalty cards.

Shortcomings of the research refer to: a) territorial limitation of the research, exclusively the regional market. An objective reason for the analysis of the CE and SEE market is the author's familiarity with the mechanisms of retail sector and habits of customers in the regional market, lower costs of the research, and the fact that the market of selected $\mathrm{CE}$ and SEE countries is suitable for analyses due to differences in economic development between groups of countries. Therefore, the obtained data can serve as a reliable landmark for other countries that are with a similar level of economic development, social/political system and level of development of the retail sector, b) In this study, seven indicators were analysed, which can lead to simplified conclusions. Objectively, there is a need to extend the analysis to subgroups within the analysed indicators.

In the context of suggestions for future research, the existing subject of the research should be extended to the analysis of the use of loyalty cards in the retail sector in other countries. The priority direction of the research would be a comparative analysis of research results between the countries from Western, Northern and Eastern Europe. Data obtained from such research would complement the scientific review of customer loyalty and benefits from the use of loyalty cards. It would be necessary to deepen the analysis on sub-groups within the existing indicators. The example would be to analyse within the indicator Price discounts whether it would be more effective to have discounts on the amount of the purchased products, individual discounts on items and special discounts.

\section{Author contribution}

The contribution of Jelena Končar is reflected in the choice of literature, defining the subject of the research and concluding observations. The contribution of Radenko Marić is reflected in the selection of the research sample, data collection and discussion. The contribution of Goran Vukmirović is reflected in statistical data processing, testing of set hypotheses and interpretation of the obtained results.

\section{Disclosure statement}

The authors declare no conflict of any competing financial, professional, or personal interests. 


\section{References}

Acatrinei, C., \& Puiu, V. T. (2012). The loyalty card: Issues in evaluating loyalty program effectiveness. International Journal of Economic Practices and Theories, 2(3), 153-164.

Alina Elena, C. (2016). Social media - a strategy in developing customer relationship management. Procedia Economics and Finance, 39, 785-790. https://doi.org/10.1016/S2212-5671(16)30266-0

Anđelković, A., \& Radosavljević, M. (2018). Improving order-picking process through implementation of warehouse management system. Strategic Managament, 23(1), 3-10. https://doi.org/10.5937/StraMan1801003A

Antonova, S. (2013). The use of loyalty program in the Bulgarian cruise industry. Montreal: Universute du Quebec a Montreal.

Anić, I. D., Rajh, E., \& Bevanda, A. (2012). Decision-making styles of young consumers in Bosnia and Herzegovina. Young Consumers, 13(1), 86-98. https://doi.org/10.1108/17473611211203966

Bakic, O., Hrabrovski-Tomic, E., Muhi, B., \& Kovacevic, J. (2010). Marketing and management implementation on megatrends in modern tourism. UTMS Journal of Economics, 1(2), 17-25.

Bell, S. J., \& Eisingerich, A. B. (2007). The paradox of customer education: Customer expertise and loyalty in the financial services industry. European Journal of Marketing, 41(5/6), 466-486. https://doi.org/10.1108/03090560710737561

Berman, B. (2006). Developing an Effective Customer Loyalty Program. California Management Review, 49(1), 123-148. https://doi.org/10.2307/41166374

Carter, B. (2016). Customer loyalty statistics: 2016 edition. Retrieved from https://blog.accessdevelopment.com/customer-loyalty-statistics-2016-edition

Carraher, S., Parnell, A. J., \& Spillan, E. J. (2009). Customer service-orientation of small retail business owners in Austria, The Czech Republic, Hungary, Latvia, Slovakia, and Slovenia. Baltic Journal of Management, 4(3), 251-268. https://doi.org/10.1108/17465260910990975

Cho, Y. J. (2019). A study on US consumers' loyalty to online shopping mall: Focused on group buying social commerce. Journal of Convergence for Information Technology, 9(2), 75-84. https://doi.org/10.26710/jbsee.v4i2.441

Danojević, A. (2016). Unapređenje lojalnosti kupaca putem potrošačkih kartica. Subotica: Faculty of Economics.

Demoulin, N. T. M., \& Zidda, P. (2008). On the impact of loyalty cards on store loyalty: Does the customers' satisfaction with the reward scheme matter? Journal of Retailing and Consumer Services, 15(5), 386-398. https://doi.org/10.1016/j.jretconser.2007.10.001

Dorotic, M., Bijmolt, T. H., \& Verhoef, P. C. (2012). Loyalty programmes: Current knowledge and research directions. International Journal of Management Reviews, 14(3), 217-237. https://doi.org/10.1111/j.1468-2370.2011.00314.x

Drinčić, D., Vranješ, M., \& Gašević, D. (2014). Consumer loyalty in retailing. School of Business Journal, 2, 91-106. https://doi.org/10.5937/skolbiz2-7397

Dunković, D., \& Petković, G. (2015). Loyalty programs in grocery retailing: Do customers provoke a tiered rewarding system? Poslovna izvrsnost, 9(1), 9-26.

Filipe, S., Henriques Marques, S., \& Fátima Salgueiro, M. (2017). Customers' relationship with their grocery store: Direct and moderating effects from store format and loyalty programs. Journal of Retailing and Consumer Services, 37, 78-88. https://doi.org/10.1016/j.jretconser.2017.03.002

Grubor, A., \& Đokić, N. (2015). Determinants of choice of global and national food products' brands. Strategic Management, 20(2), 58-67.

Huberman, B. A., Loch, C. H., \& ÖNçüler, A. (2004). Status as a valued resource. Social Psychology Quarterly, 67(1), 103-114. https://doi.org/10.1177/019027250406700109 
Jeftić, J. (2015). Modern trends in sales - phenomena of associated loyalty programs. Annals of the Faculty of Economics in Subotica, 51, 43-57.

Kellgren, C., Moradi, L., \& Romppanen, M. (2007). Customer loyality research. Jönköping: Jönköping International Business School.

Končar, J., \& Marić, R. (2015). Job satisfaction in trade sector: Evidence from the retailers in the largest supermarkets of the Western Balkans. Revija za socijalnu politiku, 22(3), 375-392. https://doi.org/10.3935/rsp.v22i3.1268

Kyguoliene, A., Zikiene, K., \& Grigaliunaite, V. (2017). The influence of perceived benefits on the satisfaction with the loyalty program. Inzinerine Ekonomika-Engineering Economics, 28(1), 101-109. https://doi.org/10.5755/j01.ee.28.1.14635

Leenheer, J., Van Heerde, H., Bijmolt, T., \& Smidts, A. (2007). Do loyalty programs really enhance behavioral loyalty? An empirical analysis accounting for self-selecting members. International Journal of Research in Marketing, 24(1), 31-47. https://doi.org/10.1016/j.ijresmar.2006.10.005

López, Á. R., \& Martín, G. R. (2019). The marketability discount in Spanish valuation multiples: investors' perception in listed companies versus private transactions. Journal of Business Economics and Management, 20(1), 107-130. https://doi.org/10.3846/jbem.2019.8101

Lovreta, S., Berman, B., Petković, G., Veljković, S., Crnković, J., \& Bogetić, Z. (2010). Customer realationship management. Beograd: Faculty of Economics and Data Status.

Lovreta, S., Končar, J., \& Petković, G. (2013). Kanali marketinga, trgovina i ostali kanali. Beograd: Univerzitet u Beogradu.

Khalil, S. M., Ullah, O., \& Khalil, D. S. H. (2018). The effect of customer loyalty programs on customer retention in Pakistan. Journal of Business and Tourism, 4(2), 237-251.

Marić, R., Radnović, B., Djuranović, D., \& Vukmirović, G. (2017). Socially responsible behavior of sales staff: evidence from Western Balkans supermarkets. Inzinerine Ekonomika-Engineering Economics, 28(1), 110-119. https://doi.org/10.5755/j01.ee.28.1.15764

Marić, R., \& Kraleva, V. (2017). Loyalty programs in the function of customer relationship strategy. The Annals of the Faculty of Economics in Subotica, 53(38), 251-264.

Melnyk, V., Van Osselaer, S. M., \& Bijmolt, T. H. (2009). Are women more loyal customers than men? Gender differences in loyalty to firms and individual service providers. Journal of Marketing, 73(4), 82-96. https://doi.org/10.1509/jmkg.73.4.82

Mercadé-Melé, P., Molinillo, S., Fernández-Morales, A., \& Porcu, L. (2018). CSR activities and consumer loyalty: The effect of the type of publicizing medium. Journal of Business Economics and Management, 19(3), 431-455. https://doi.org/10.3846/jbem.2018.5203

Pesonen, J., Komppula, R., \& Murphy, J. (2019). Plastic loyalty - Investigating loyalty card programs for a Finnish hotel chain. Tourism Management, 73, 115-122.

https://doi.org/10.1016/j.tourman.2019.01.023

Plazibat, I., Šušak, T., \& Šarić, T. (2016). Functionality of customer loyalty programs in retail. Ekonomska misao i praksa, 1, 303-318.

Putra, A. P., Armanu, A., \& Sudjatno, S. (2019). The influence of corporate social responsibility, brand personality and corporate reputation on brand loyalty of modern retailers. Jurnal Aplikasi Manajemen, 17(1), 66-75. https://doi.org/10.21776/ub.jam.2019.017.01.08

Rao, D., \& Kotian, R. R. (2018). The impact of loyalty cards in retaining customers: A study with reference to mega mart retail outlet in mangalore city. Anveshana, 8(1), 103-124.

https://doi.org/10.23872/aj/2018/v8/i1/176267

Reinartz, W. J. (2010). Understanding customer loyalty programs. In M. Krafft \& M. Mantrala (Eds.), Retailing in the 21st century. Berlin: Springer Berlin Heidelberg.

https://doi.org/10.1007/978-3-540-72003-4_25 
Tekić, T. (2018). Development of B2C e-commerce in the European Union countries. Annals of the Faculty of Economics in Subotica, 54(40), 171-182. https://doi.org/10.5937/AnEkSub1840171T

Vesel, P., \& Zabkar, V. (2009). Managing customer loyalty through the mediating role of satisfaction in the DIY retail loyalty program. Journal of Retailing and Consumer Services, 16(5), 396-406. https://doi.org/10.1016/j.jretconser.2009.05.002

Vilkaite-Vaitone, N., \& Papsiene, P. (2016). Influence of customer loyalty program on organizational performance: A case of airline industry. Inzinerine Ekonomika-Engineering Economics, 27(1), 109116. https://doi.org/10.5755/j01.ee.27.1.10267 